\title{
Environmental terrorism and socio-economic factors in the mechanism of countering terrorist crimes
}

\author{
Irina Danilova ${ }^{1}$, Olga Knyazeva $^{1, *}$, Svetlana Mayorova ${ }^{1}$, and Liliana Peremolotova ${ }^{1}$ \\ ${ }^{1}$ Academy of the Federal penitentiary service of Russian Federation, 1 Sennaya str., Ryazan, 390000 , \\ Russian Federation
}

\begin{abstract}
In the modern period of the widespread processes of globalization, integration and rapid migration, complicated foreign policy relations of a number of states belonging to transnational blocs defending opposing interests, of course, the problem of effectively countering terrorist and extremist activities, as well as preventing the spread of relevant ideologies, is becoming particularly acute. The international community, realizing the danger of terrorism and striving to develop effective measures to prevent it, has adopted a number of documents, which include United Nations conventions (for example, the International Convention for the Suppression of the Taking of Hostages, the International Convention for the Suppression of Terrorist Bombings, the International Convention for the Suppression of financing of terrorism). The increased importance of this type of crime is also confirmed by the consolidation in federal legislation of the relevant concepts and forms in which the considered illegal activity can be carried out, the methods of its prevention and sanctions used for committing offenses of an extremist and terrorist nature. The main normative legal acts in this area are the federal laws of July 25, 2002 No. 114-FZ "On Countering Extremist Activity" and of March 6, 2006 No. 35-FZ "On Countering Terrorism." For the purposes of criminal law enforcement of countering terrorism and in the interests of fulfilling international obligations, the Criminal Code of the Russian Federation of June 13, 1996 (as amended on November 28, 2015, hereinafter referred to as the Criminal Code of the Russian Federation) establishes responsibility for the commission of crimes against international security.
\end{abstract}

\section{Introduction}

In connection with the growth of terrorist activities, the problem of increasing involvement of adolescents in promotion of terrorist activities has become most acute. An appeal to the group of young people where extremist attitudes are in the process of formation allows us to trace the genesis of this phenomenon and effective forms of control. The increase in the proportion of young people in terrorist groups is a consequence of

*Corresponding author: knyazeva@yandex.ru 
transformation processes taking place in modern Russian society, and is largely associated with destruction of existing value system, family institutions, education, social protection of young people, but most importantly, with the economic crisis.на

For a certain part of adolescents, terrorism is a kind of extreme sport and dangerous entertainment. In fact, terrorism is an instrument of power. Not a state one, but one that emerges in any mass organizations fighting for recognition in the political process.

The purpose of the study is to analyze criminal-legal characteristics of promotion of terrorist activities and develop proposals for improving current legislation of Russian Federation in this area.

To achieve this goal, it is necessary to fulfill the following tasks:

- to determine public danger of assisting terrorist activities;

- to establish objective signs of composition of assistance to terrorist activities and problem of their establishment in the process of qualifying the deed;

- to study subjective signs of composition of assistance to terrorist activities and problems of their establishment in the process of qualifying the offense;

-to consider differences between facilitating terrorist activities and terrorist acts;

- to analyze statistical data (2010-2020) on the number of registered extremist crimes (Diagram 1);

-to consider differences in the promotion of terrorist activities and sabotage;

- to formulate proposals for improving the criminal legislation in the part related to the problem of competition between norms of general and special parts of Criminal Code of Russian Federation.

The analysis of the objective aspect of composition of assistance to terrorist activities indicates that it, in fact, consists of preparation, incitement to commit terrorist crimes. In other words, at present, qualification of assistance to terrorist activities is associated with the problem of competition between general and special norms. In turn, this competition is actually transformed into a collision between the provisions of General and Special parts of the Criminal Code of Russian Federation, because within the framework of the latter, without any justification, preparation is recognized as a completed crime, and incitement and aiding - the execution of a crime. Moreover, the positions of these parts in semantic terms, and, often, literally duplicate each other.

If we consider an integrated, comprehensive approach to solving the problem of increasing the effectiveness of criminal law in the field of countering terrorism and extremism, then it involves implementation of three key areas. In the field of criminal law, it is necessary to develop a national mechanism for criminal-legal measures to counter terrorism and extremism, taking into account international standards and a constitutional approach to the design of criminal law norms; determination of key areas for improving the rule-making activity in the field of structuring and modeling criminal law norms that ensure state and public security; introduction of evaluative criteria for the effectiveness of criminal law in the field of countering extremism and terrorism.

In the field of criminology, the study of determinants of terrorist and extremist crimes seems relevant; development of a methodology for researching personality of a criminal infringing on public safety, including the characteristics of personality of a criminal who commits a terrorist act; determination of the main directions for increasing the effectiveness of prevention of terrorist and extremist acts; making proposals for improving individual preventive activities, including in relation to certain categories of convicts; study of personality of offender and characteristics of the impact on legal consciousness in conditions of correctional institutions; implementation of psychocorrectional programs and other innovative techniques.

In the field of criminal executive law, the study of social conditioning of recidivism in the field of public safety is justified; carrying out a comprehensive legal assessment of 
effectiveness of imposed criminal punishment and other measures of a criminal-legal nature, taking into account the transnational nature of crimes, peculiarities of Russian legal system and prevailing socio-economic and political-legal realities; Conducting a content analysis of court sentences in criminal cases related to a terrorist act for their preventive effectiveness.

\section{Methods}

If twenty years ago, experts in the field of criminology, political science and other sciences related to the sphere of crime in question stated the fact that extremism in general and terrorism as an element of its component do not tend to grow and their local foci can be confidently eliminated at an early stage emergence, then at the moment the authors emphasize the seriousness of the threat that these radical ideologies carry for normal functioning of society, the integrity of the state, as well as the rights, freedoms and legitimate interests of citizens (Kochoi S.M. (Moscow, 2005)). According to S.V. Dyakova, (St. Petersburg, 2009) criminal liability for a terrorist act was introduced in full in the Criminal Code in 1926. Considering the main stages in the development of domestic criminal legislation on responsibility for assisting terrorist activities, A.G. Meretukov. (Krasnodar, 2014) noted that the USSR joined the relevant international documents quite late, therefore, responsibility for terrorism and knowingly false reporting of an act of terrorism in the criminal law was established only in 1994.

In the scientific literature, we have met such a statement by A.V. Serebryakov. (Krasnodar, 2012) that the promotion of terrorist activities in the form of involving in the commission of crimes of a terrorist nature of a person who is obviously not subject to criminal liability (due to age, insanity or other circumstances), forms a set of Art. 205.1 and Art. 205, 206, 208, 211, 277 or 360 of the Criminal Code of Russian Federation. It is logical to consider the involvement of minors in committing crimes of a terrorist nature as a mediocre execution of corresponding socially dangerous acts, but qualifications in this situation under Art. 205 of Criminal Code of Russian Federation is impractical. Attention was paid to the topic under study and the object of these crimes by A.A. Piontkovsky (Moscow, 1961). He rightly noted that the object of any crime is social relations, protected by the apparatus of criminal law enforcement.

In the process of carrying out this scientific research, the dialectical method of scientific cognition, private scientific methods of researching social and legal phenomena, including historical method of cognition, were used. as well as formal-logical, historical-legal, comparative-legal, statistical, system-structural methods.

\section{Results}

The study showed that development of Russian criminal legislation on criminal liability for assisting terrorist activities was mainly of an evolutionary nature and proceeded in two directions: both along the lines of its General part (within the framework of institutions of unfinished crime and complicity in a crime), and Special parts (within the framework of certain elements of state crimes and crimes against public security). In order to resolve all controversial issues related to the qualification of assistance to terrorist activities and its relationship with related crimes, a special resolution of the Plenum of the Supreme Court of Russian Federation should be adopted. 


\section{Discussion}

Considering the process of development of legislation, including criminal legislation, in modern conditions is complicated by the constant emergence of new types of encroachments, recognized in society as criminal. These difficulties concern not only the special part of the Criminal Code. So, for example, difficulties of applying the institution of complicity are usually focused on the assessment of such a feature as joint participation of several persons in the commission of a deliberate crime, or rather, on the criminal-legal assessment of forms of expression of such joint activity.

In our opinion, the crimes under Art. 205, art. 205.1, art. 208, 209, 210, 212, 239, 279, 282-1, 282-2 of Criminal Code of Russian Federation are designed by the legislator in such a way that an act in one form or another provided for by the disposition of the norm acts as a basic feature of the objective side. Socially dangerous consequences are taken out by the legislator outside the framework of respective compositions. It seems that socio-legal assessment of socially dangerous consequences of crimes under consideration, as well as the fact that they are taken outside the scope of composition, deserve some attention.

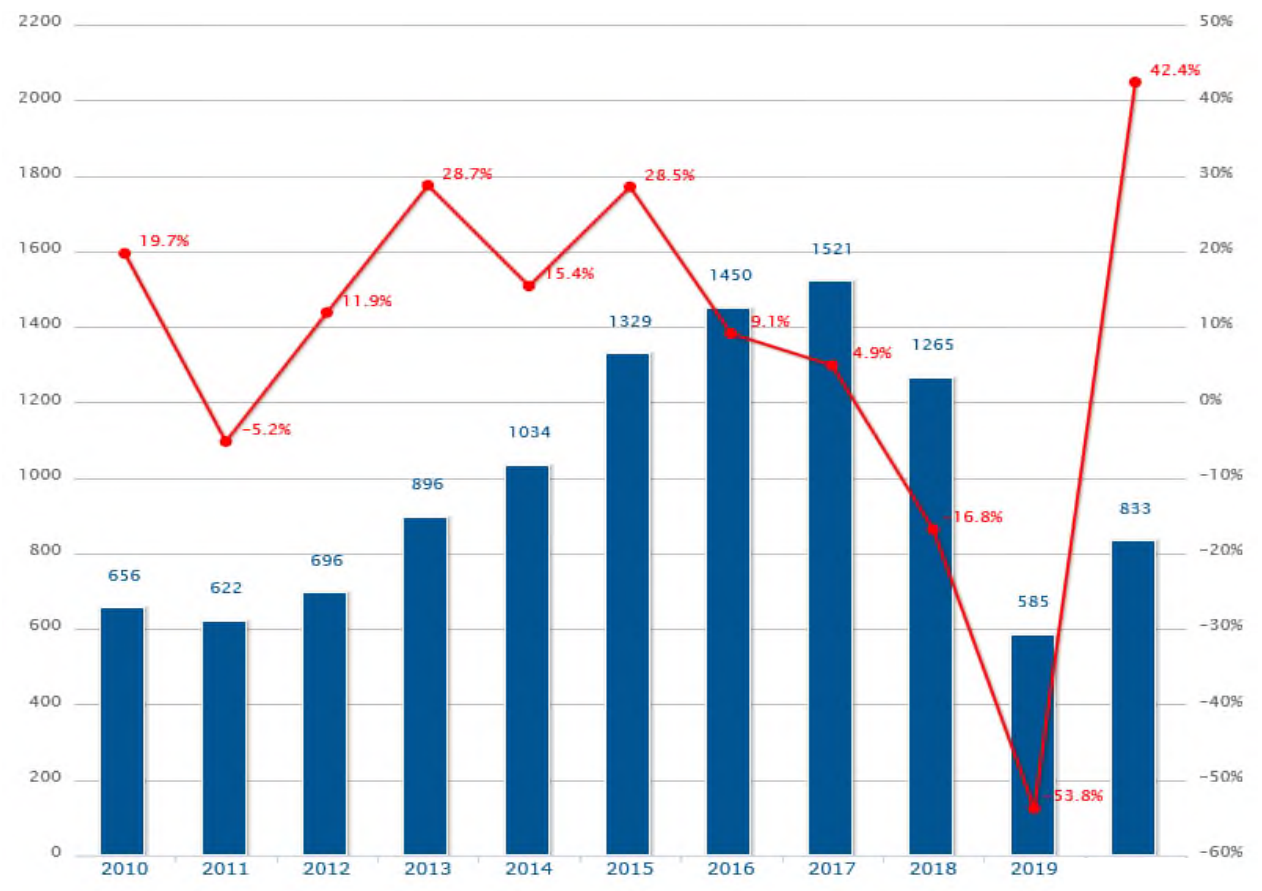

Fig. 1. Number of extremist crimes.

In a number of cases, when qualifying crimes committed with complicity, it is necessary to resolve the issue of delimiting incitement as a type of complicity from crimes, the objective side of which is actually formulated in the disposition as actions of an accomplice.

An independent problem of qualification is criminal-legal assessment of organized forms of criminal activity.

In the theory of criminal law and criminology, the concept of organized crime is sufficiently developed, and methods of combating its manifestations are also covered in detail. However, in practice, qualification of organized criminal acts is often associated with significant difficulties. This is largely due to the difficulty of distinguishing between 
organized and unorganized group criminal acts committed by prior collusion, since any collusion presupposes certain elements of organization.

It seems to us methodologically correct to link the beginning of qualification process with the establishment of signs of preliminary collusion and accompanying distribution of roles.

The considered crime has one more peculiarity. It shows that a group of persons, united to commit a crime, as it functions, can acquire the characteristics of an organized group. There is a kind of "mutation" of a complex form of complicity - from complicity by prior conspiracy by a group of persons with distribution of roles to an organized criminal group. Such a modification is possible only against the background of a long-term existence of a criminal group.

Development and modification of this or that form of participation in the process of its existence and functioning is an independent problem of qualifying complex forms of participation.

There is no doubt that the functionality of grading the forms of complicity into simple and complex ones, as well as complex ones within this group, is associated with the establishment of degree of public danger of one form or another of complicity. In this regard, the authors propose measures to improve Russian legislation aimed at fighting terrorist crimes.

The text of the Federal Law of July 25, 1998 "On the fight against terrorism" also needs to be clarified. Art. 3 of the Law gives basic concepts: terrorism, terrorist act and crimes of a terrorist nature. An analysis of the last two terms allows us to unambiguously conclude that the taking of a hostage is recognized as a terrorist act and a crime of a terrorist nature, along with the crimes provided for in Art. 205,207, 208, 277 and 360 of the Criminal Code of Russian Federation.

Thus, at the present stage of development of society, current criminal law needs to be changed and clarified, which will make it possible to more accurately determine the signs of both the investigated corpus delicti and related elements. Along with the criminal law, there is a need to improve other legislative acts, which will play a positive role in law enforcement.

\section{Conclusion}

Summing up, the authors would like to note that the crime in question is a complex, multifaceted phenomenon.

Having analyzed the ratified international conventions of universal and regional levels, we can conclude that for more than four decades of the XX century. a fairly broad understanding of promotion of terrorism has been formed, which can be expressed both in any deliberate activity to provide intellectual (training, instructing, providing information, etc.) and / or material (financing, recruiting, providing weapons, etc.) ) assistance aimed at ensuring the unhindered and systematic commission of terrorist crimes. Thus, "assistance" is defined not only as direct complicity in the commission of specific crimes of a terrorist nature, but also as indirect complicity in the form of various forms of support for terrorism.

Speaking in general about the allocation of assistance to terrorist activities, as an independent crime, in our opinion, it is necessary to leave only three forms of such assistance, namely: armament, training of a person in order to commit at least one of the crimes provided for in Art. 205, 205.2, 205.3, 205.4, 205.5, 206, 208, 211, 220, 221, 277, 278, 279, 360 and 361 of the Criminal Code of Russian Federation, as well as financing or other material support of terrorism.

At present, qualification of assistance to terrorist activities is associated with the problem of competition between general (part 1 of article 30, part 4 and 5 of article 33 of 
the Criminal Code) and special (article $205^{1}$ of the Criminal Code of Russian Federation) norms, since this assistance, in fact, consists in preparation for a crime, incitement to it or complicity in its commission. In turn, this competition is actually transformed into a collision between the provisions of General and Special parts of the Criminal Code of Russian Federation, because within the framework of the latter, without any justification, preparation is recognized as a completed crime, and incitement and aiding - the execution of a crime.

In order to resolve all controversial issues related to the qualification of assistance to terrorist activities and its relationship with related crimes, a special resolution of the Plenum of the Supreme Court of Russian Federation should be adopted. In particular, within the framework of the latter, it would be advisable to give the following clarification: "The actions of a person who persuaded, recruited, or otherwise involved another person to commit at least one of the crimes provided for in Articles 205, 206, 208, 211, 277, 278, 279 and 360 of the Criminal Code of Russian Federation form a set of crimes and must be qualified under Art. $205^{1}$ of the Criminal Code as an act of perpetrator of assisting terrorist activities and, depending on specific circumstances of the case, as an act of an instigator or accomplice in the commission of a corresponding crime of a terrorist nature with reference to Part 4 or Part 5 of Art. 33 of the Criminal Code of Russian Federation".

\section{Acknowledgments}

The authors express their deep gratitude to the leadership of the Academy of Federal Penitentiary Service of Russia for the help and support provided during this study.

\section{References}

1. S.M. Kochoi, Abstract journal 2, 110 (2006)

2. S.V. Dyakov, Crimes against the foundations of constitutional system and state security $(\mathrm{SPb}, 2009)$

3. A.G. Meretukov, Bulletin of the Krasnodar University of the Ministry of Internal Affairs of Russia 4(26), 42 (2014)

4. A.V. Serebryakov, Assistance to terrorist activity: problems of qualification and correlation with related corpus delicti: dis. ... Ph.D of legal sciences (Krasnodar, 2012)

5. A.A. Piontkovsky, Teaching about crime in the Soviet criminal law (M., 1961)

6. V. Lez'Er, N. Semerianova, A. Kopytova, Y. Truntsevsky, E3S Web of Conferences 110, 02093 (2019) DOI: 10.1051/e3sconf/201911002093

7. A.V. Kopytova, N.S. Zotkina, I.G. Reshetnikova, MATEC Web of Conferences 239, 04012 (2018) DOI: 10.1051/matecconf/201823904012

8. V. Lez'Er, N. Semeryanova, A. Kopytova, I. Kvach, E3S Web of Conferences 110, 02094 (2019) DOI: 10.1051/e3sconf/201911002094

9. R. Kolobov, U. Filatova, V. Borshcheniuk, N. Semerianova, D. Bayanov, E3S Web of Conferences 110, 02095 (2019) DOI: 10.1051/e3sconf/201911002095

10. Y.V. Truntsevsky, I.I. Lukiny, A.V. Sumachev, A.V. Kopytova, MATEC Web of Conferences 170, 01067 (2018) DOI: 10.1051/matecconf/201817001067

11. N. Semeryanova, O. Fedorenko, A. Kopytova, MATEC Web of Conferences 239, 04013 (2018) DOI: 10.1051/matecconf/201823904013

12. M.S. Gusarova, A.V. Kopytova, I.G. Reshetnikova, Periodico Tche Quimica 16(31), 903-912 (2019) 
13. V. Lez'Er, I. Muratova, A. Grigorev, A. Kopytova, E3S Web of Conferences 91, 08068 (2019)

14. Y. Truntsevsky, V. Lez'er, S. Belyasov, A. Kopytova, E3S Web of Conferences 157, 03016 (2020) 